loans which the company is expected to secure from the banks. Help is also to be provided for ICL's research and development programme which last year consumed about 8 per cent of the company's £715 million turnover.

Sir Keith's intervention is seen as a major blow to the Conservative government's policy of not interfering in private industry. But the decision was taken only after several months of searching for private investors had found no takers. The chief justification for supporting ICL when other private industries are allowed to go to the wall seems to be that the smooth operation of many government offices depends heavily on its computers.

ICL is something of a favourite of British governments. When it was created in 1968 from the amalgamation of two computer companies, the government retained a substantial shareholding and supported it heavily during its early years both with cash and with awards of almost all contracts for large computers for government departments. In the 1970s, the company became profitable and in late 1979, Mrs Thatcher's government sold off its shares. But only 18 months later, ICL's profits took a lurch.

Precisely why the company's fortunes changed so suddenly seems to be a mystery. The company itself says that the world recession combined with the strong value of the pound and high interest rates is responsible. There were hints of trouble, it says, in the first half of 1980 but during the second half both home and overseas orders fell off markedly. Others have said that poor management, a concentration on large computers when the market is moving towards desk-top machines, spending too much on parts of the business not connected with manufacturing and even underpricing goods, are also responsible.

Neither the government nor the banks, however, seem to have stipulated conditions for the $£ 200$ million loan. The company hopes to ride out the recession by continuing business much as before and economizing wherever possible. It says, for example, that its research and development programme will continue at much the same level as last year, with the same mix of research on large and small machines. One of the projects on which it pins hopes for the future is the large Distributed Array Processor which has so far been sold to the British National Oil Corporation, for seabed exploration, and Queen Mary College University of London. The Science Research Council is considering buying one for its Rutherford or Daresbury laboratories.

Sir Keith Joseph hopes that the government will not have to make good its guarantee, believing that the loan will see ICL through the recession until business picks up again. Meanwhile, the net is still being cast far and wide in the hope of finding private investment on suitable terms.

Judy Redfearn
London medical schools Mergers galore

The University of London has made a modest beginning on the reorganization of its twelve medical schools. Last week, the senate of the university approved a plan to save something like $£ 5$ million a year, or ten per cent of the present cost to the university of medical education. Some two-thirds of the saving will come from a general reduction of staff-student ratios throughout the medical schools.

The accompanying reorganization of the London medical schools is only a pale shadow of the grand design put forward more than a year ago by a committee under Lord Flowers, rector of Imperial College. At the senate meeting last week, it was formally agreed that the Westminister Hospital Medical School (a clinical school now recruiting about 100 students a year) should be merged with the medical schoo at Charing Cross Hospital (now located in West London). Other proposed groupings of medical schools have been given until later in the year to work out how they will coordinate their teaching.

The Westminster school considers itself unfairly singled out by these developments. Ever since the publication of the Flowers Report, Westminster has been urging the benefits of small medical schools, complaining that its students or their successors will be lost in a medical school with an annual intake of 180 , the planning figure for clinical students at Charing Cross. It also says that the efforts that have been made in the past year or so to coordinate teaching between the two hospitals may be jeopardized by the shotgun marriage now decreed. Given forward commitments to students, it may be as much as five years before teaching comes to an end on the Westminster site.

In retrospect, the schools least affected by the changes now proposed are those at Guy's Hospital and St Thomas's Hospital, which announced last year that they would form a joint school, with a single governing body, but would continue to operate on both the present sites. This arrangement has now been sanctioned by the university senate. The other consortia from which the university is seeking financial savings are University College, Middlesex and St Mary's, which are required between them to save the equivalent of one clinical and one preclinical school; St Bartholomew's and the London Hospital, which have been given until June to suggest how they will merge; and King's College (which has a preclinical school) and King's College Hospital, which seem to be willing to fall in with the recommendation that they should form an integrated unit.

The proposals accepted last week by the senate were recommended by the Joint Planning Committee on Medical Education, set up to pilot the Flowers Report through the university. In the past year, and especially as a result of a detailed analysis of the costs of the London medical schools carried out by a firm of accountants, it became clear that changes of staffstudent ratios offered the most rapid route to cost reductions. The committee accepts as a standard for future staffing a ratio of $1: 10$ for preclinical schools and 1:7 for clinical schools. This would mean the loss of 180 academic posts, which it is hoped can be achieved by natural retirement and wastage in the next five or six years.

Running through the report of the joint committee is the view that medical education should be concentrated in larger units than at present, especially where modern buildings have been provided. In this spirit, the committee recommends that the development of the St George's Hospital site in South London should be continued. The future of the postgraduate medical institutes remains entirely open, however. With the exception of the Institute of Dermatology (which is to merge with St Thomas's Hospital Medical School), the institutes have been seriously affected by the reductions in the past year in the numbers of overseas students. The university is hoping that central government will help bail them out, but no decision has yet been reached.

Last week's decision by the university senate is likely to be regarded, within the University of London, as some kind of precedent for the reorganization of the non-medical parts of the university likely to be recommended by the Swinnerton-Dyer committee, due to report in September, and elsewhere as a sign that, if pressed hard, even British universities can change their ways.

\section{Law of the Sea}

\section{US backtracks}

\section{Washington}

The Reagan Administration's decision to carry out a complete review of the US position on the draft Law of the Sea Treaty, now under discussion at the United Nations in New York, indicates that significant new attitudes may emerge towards international resource disputes ranging from the surface of the Moon to the minerals of the Antarctic continent.

The United States is considering whether to adhere to the concept that natural resources which lie outside the immediate political domain of individual nations should be treated as "the common heritage of mankind" - a term coined by the United Nations - or whether, in the name of free enterprise and the national security implications of a shortage of strategic minerals such as cobalt and manganese, this concept should be abandoned, together with attempts to set up international regulationsto control exploitation.

A new twist to the Law of the Sea negotiations comes from the likely take-over of the Kennecott Corporation, a leading critic 
of the United States' negotiating position, by Standard Oil of Ohio (Sohio). Sohio is 53 per cent owned by British Petroleum, which in turn is 45 per cent owned by the British government. In the past, BP Minerals, a member with Kennecott of one of the five consortia interested in deep-sea mining, has been keen to finalize the treaty to protect its existing exploration and mining operations.

In theory, a Sohio/Kennecott deal could favour a successful outcome to the Law of the Sea negotiations. In practice, the outcome could depend more on whether the Reagan Administration listens to arguments from international companies that a treaty is essential to the security of their future trading operations, or whether it gives greater weight to conservative pressure groups arguing that the whole "common heritage" concept, along with Third World demands for a "new international economic order", should be dismissed as socialist subversion.

In dismissing several key members of the US negotiating team, and initiating a complete review of the treaty in its draft form, the Reagan Administration is responding to complaints from groups such as the Council on Economics and National Security. Council officials were among the principal authors of a warning by the American Geological Institute to the two presidential candidates last September of a Soviet "resource war" aimed at depriving the United States of materials indispensable to its national defence.

Immediately after the election, the Reagan Administration set up a task force on national strategic minerals policy, which recommended a complete review of the draft Law of the Sea Treaty. One of the principal opponents of the treaty in its present form is a Washington attorney, Leigh Ratiner, acting head of the Department of the Interior's office of oceans and minerals under President Ford, and later the chief lobbyist on the treaty for the Kinnecott Corporation.

Mr Ratiner is acting as counsel to the L-5 society, a 4,000-strong group of scientists and "futurists". The society is largely credited with stalling any effort by the Senate to ratify a draft treaty covering mining operations on the Moon, agreed in principle by the United Nations last year.

Particularly strong opposition to the treaty has been voiced by the US Steel Corporation of Pittsburgh, a leading partner in the Ocean Mining Associates consortium. According to the chairman of US Steel, William R. Roche, policies pursued by the Carter Administration tended to increase the country's strategic mineral vulnerability.

Attempts to scuttle the Law of the Sea negotiations have been fiercely attacked by Mr Carter's chief negotiator Mr Eliot Richardson, ex-ambassador to the United Kingdom, who warned that many multinational companies would face severe consequences if they tried to disrupt agreements that had already been reached by US negotiators in good faith.

Many conservatives, however, see $\mathrm{Mr}$ Richardson's position as symptomatic of a "soft" approach to the Third World that does little to protect US economic and strategic interests. A change in strategy on the Law of the Sea Conference could also have implications for other negotiations.

Following the Antarctic Treaty of 1959 , the 12 (now 14) nations laying claim to Antarctic territory have agreed voluntarily to restrain mining activities until an appropriate international treaty can be worked out. Yet this too is now being challenged by conservatives within the Reagan Administration, largely on the grounds that negotiations could result in the United States gaining less than it might expect from an international free-for-all, given its superiority in mining technology.

Delegates attending the Law of the Sea negotiations session in New York, although dismayed with the Reagan Administration's position, have agreed to

\section{India mines the sea}

\section{New Delhi}

India has become the first developing country to collect polymetallic nodules from the ocean floor, a distinction achieved by India's first research ship, the Gaveshani. The 1,900-tonne vessel, once a hopper barge and converted into a research ship in 1975, is operated by the National Institute of Oceanography (NIO) in Goa, one of the 40 institutes under the aegis of the Council of Scientific and Industrial Research.

NIO has been preparing the Gaveshani for nodule hunting since 1978 and the catch was made in January during her cruise from Goa to Mauritius, which was led by Dr S.Z. Qasim, director of NIO.

According to Dr Qasim, the Gaveshani located a nodule-rich region in the Indian Ocean about 700 miles from the mainland and reaching almost as far as Mauritius. During the return journey the ship collected more nodules from several locations at depths of 3,600-5,400 metres.

Besides nickel, cobalt, copper, manganese and iron, the samples are believed to contain traces of gold, but their precise metallic contents are now being analysed by eight Indian laboratories.

The Gaveshani's nodule collecting gear

Gaveshani - hunting for nodules discuss the details of the draft treaty. Some had hoped that the Kennecott/Sohio deal, together with the influence of other international groups such as Royal Dutch Shell, might help to dilute the pressure of more nationally-oriented companies on the Reagan Administration.

Meanwhile, a group of lawyers, scientists, environmentalists and economists has issued a report calling for research into the character of the marine environment of the deep ocean, and its susceptibility to mining operations. The group points out that no explicit mention is made of the need for prior environmental assessment either in a bill on deep-sea mining rights passed recently in West Germany, or in draft bills now before French and British legislatures. It was also concerned that such nations might get together with the United States and other countries to set up their own institution for regulating mining activities before the Law of the Sea negotiations finally break down.

David Dickson

consisted of a 10,000-metre winch, underwater camera, dredges and some twenty "boomerang grabs", which go down to pick up the nodules and come up automatically. According to Dr Qasim, the surveyed seabed area had a nodule concentration of 1 to 5 kilogrammes per square metre, which is potentially economic for mining.

India is not ready to start mining proper, but NIO plans to map the nodulerich region to assess its total mineral wealth. The operation should be speeded up next year when the Gaveshani is joined by a second research ship now under construction in West Germany. Since India imports all its nickel and cobalt and more than 60 per cent of its copper requirements, the discovery of a nodule basin in its close vicinity should be welcome news.

There is a long haul between picking up a few seabed nodules and being able to mine them commercially. Yet the Gaveshani's demonstration has raised some eyebrows among nations that at present have a monopoly on ocean mining. It is likely that United Nations talks on the Law of the Sea will acquire a new dimension as a result of India's unexpected entry into the ocean mining club.

K.S. Jayaraman 